\title{
The effects of intraruminal infusions of urea, casein, glucose syrup and a mixture of casein and glucose syrup on nitrogen digestion in the rumen of cattle receiving grass-silage diets
}

\author{
BY J. A. ROOKE, N. H. LEE* AND D. G. ARMSTRONG \\ Department of Agricultural Biochemistry and Nutrition, University of Newcastle \\ upon Tyne, Newcastle upon Tyne NE1 $7 R U$
}

(Received 21 November 1985 - Accepted 14 August 1986)

1. In an incomplete $5 \times 5$ Latin square experiment, four cattle were given grass silage in two meals per $\mathrm{d}$ to satisfy 1.15 maintenance energy requirements. In addition, water or casein $(21 \mathrm{~g}$ nitrogen and $0.17 \mathrm{~kg}$ organic matter $(\mathrm{OM}) / \mathrm{d})$ or urea $(\mathrm{U} ; 28 \mathrm{~g} \mathrm{~N} / \mathrm{d})$ or a glucose syrup $(\mathrm{G} ; 0.87 \mathrm{~kg} \mathrm{OM} / \mathrm{d})$ or casein and glucose syrup (CG; $17 \mathrm{~g} \mathrm{~N}$ and $0.93 \mathrm{~kg} \mathrm{OM} / \mathrm{d}$ ) were infused intraruminally at a constant rate.

2. A 24 h collection of duodenal digesta was made using chromic oxide for flow estimation and ${ }^{35} \mathrm{~S}$ as a marker of microbial $\mathrm{N}$ entering the small intestine. Samples of rumen fluid were also taken for estimation of rumen $\mathrm{pH}$, and concentrations of ammonia- $\mathrm{N}$ and volatile fatty acids.

3. The intraruminal infusions had no significant effects on rumen $\mathrm{pH}$, concentrations of volatile fatty acids or their molar proportions. Infusion of either $\mathrm{C}$ or $\mathrm{U}$ significantly $(P<0.05)$ increased rumen $\mathrm{NH}_{3}-\mathrm{N}$ concentrations whereas infusions of either $\mathrm{G}$ or $\mathrm{CG}$ lowered rumen $\mathrm{NH}_{3}-\mathrm{N}$ concentrations.

4. Infusions of $\mathrm{C}$ or $\mathrm{U}$ had no significant effect on the quantities of $\mathrm{OM}$, acid-detergent fibre (ADF) or $\mathrm{N}$ constituents which entered the small intestine.

5. Infusions of $\mathrm{G}$ or $\mathrm{CG}$ increased the quantities of $\mathrm{OM}$ (G $P<0.05$, CG $P<0.01$ ), ADF (CG $P<0.05$ ), non- $\mathrm{NH}_{3}-\mathrm{N}(\mathrm{G} P<0.05, \mathrm{CG} P<0.01)$, amino acid N (G $\left.P<0.05, \mathrm{CG} P<0.01\right)$ and microbial N $(\mathrm{G} P<0.05$, CG $P<0.01$ ) which entered the small intestine.

6. The efficiency of rumen microbial $\mathrm{N}$ synthesis was unchanged by the infusion of $\mathrm{C}, \mathrm{U}$ or $\mathrm{G}(P>0.05)$ but increased significantly $(P<0.05)$ when $C G$ were infused.

During ensilage, the soluble carbohydrates $(\mathrm{CHO})$ present in grass are fermented to lactic acid and volatile fatty acids by anaerobic bacteria. Extensive proteolysis of the herbage protein also takes place chiefly as a result of the activity of plant proteases (McDonald, 1981). Thus when silage is given to ruminant livestock the major $\mathrm{CHO}$ substrates available for rumen fermentation are the slowly fermented plant cell walls whilst most of the nitrogenous substrates available for rumen microbial synthesis are soluble and are present in silage in the form of non-protein-nitrogen, e.g. ammonia and amino acids. The efficiency of microbial $\mathrm{N}$ synthesis in the rumen in animals given silage is markedly lower than the value of $32 \mathrm{~g} \mathrm{~N} / \mathrm{kg}$ organic matter (OM) apparently digested in the rumen (OMADR), adopted by the Agricultural Research Council (ARC, 1984), with most values being in the range 25-30 g N/kg OMADR (for example, see Thomson et al. 1981; Chamberlain et al. 1982; Rooke et al. 1983 b).

Supplementation of grass silage with barley has proved largely ineffective in stimulating the efficiency of rumen microbial $\mathrm{N}$ synthesis (Thomas et al. 1980; Rooke et al. 1985a) whereas consistent responses have been obtained by supplementing silage given to cattle with soya-bean meal (Brett et al. 1979; Rooke et al. 1983a, 1985a), although not with sheep (Siddons et al. 1979). The experiment reported here was designed to establish whether these responses to soya-bean meal supplementation were a response to the release in the rumen of additional $\mathrm{NH}_{3}-\mathrm{N}$ or of amino acids and peptides; a further objective was to investigate whether a rapidly fermentable soluble $\mathrm{CHO}$ would prove effective in stimulating microbial

* Present address: Korea Advanced Institute of Science and Technology, PO Box 131, Dong Dae Mun, Seoul, Korea. 
Table 1. The chemical composition $(\mathrm{g} / \mathrm{kg}$ dry matter) of the silage

\begin{tabular}{lc}
\hline $\mathrm{pH}$ & $3 \cdot 8$ \\
Dry matter $(\mathrm{g} / \mathrm{kg})^{*}$ & 229 \\
Organic matter & 934 \\
Acid-detergent fibre & 364 \\
Neutral-detergent fibre & 738 \\
Water-soluble carbohydrate & 61 \\
Total nitrogen & $18 \cdot 4$ \\
Amino acid-N & $12 \cdot 5$ \\
Ammonia-N & $1 \cdot 2$ \\
Formic acid & 22 \\
Acetic acid & 19 \\
Lactic acid & 111 \\
Ethanol & 69 \\
\hline
\end{tabular}

* Determined by toluene distillation.

$\mathrm{N}$ synthesis in the rumen. Cattle fed on grass silage were supplemented with intraruminal infusions of water (W, control) or urea (U), casein (C), glucose syrup (G), or $C$ and $G$. The effects of these infusions on the entry of microbial $\mathrm{N}$, undegraded feed $\mathrm{N}$ and other constituents into the small intestine were measured.

\section{EXPERIMENTAL \\ Animals}

Four female Jersey cattle, aged between 4 and 5 years, had mean (with SE) weights of 409 (SE $21 \cdot 5) \mathrm{kg}$ at the beginning of the experiment. Each animal was equipped with a rumen cannula and a re-entrant cannula in the proximal duodenum (McMeniman \& Armstrong, 1979).

\section{Diets and experimental procedure}

The animals were fed on grass silage throughout the experiment and in addition each animal was infused intraruminally with each of five different solutions in turn according to an incomplete $5 \times 5$ Latin square experimental design.

The grass silage was prepared from a first cut of predominantly perennial ryegrass (Lolium perenne) containing some white clover (Trifolium repens), harvested with a precision-chop forage harvester on 7 June 1983. The grass was wilted for $24 \mathrm{~h}$ and ensiled by means of an Eberhard Silopresse (Benedict Agricultural Ltd, London) with the application of an additive containing $850 \mathrm{~g}$ formic acid $/ \mathrm{kg}$ (Add-F; BP Nutrition UK Ltd). The silo was opened after $210 \mathrm{~d}$ and from then on silage was removed at weekly intervals, weighed and stored in tightly closed plastic bags at room temperature. The composition of the silage is given in Table 1.

The silage was offered to each animal twice daily in equal amounts at 08.00 and 16.00 hours throughout the experiment. The amount of silage offered supplied sufficient metabolizable energy to provide 1.15 times the maintenance energy requirements of each animal, calculated from the live weight of the animal at the start of the experiment (Ministry of Agriculture, Fisheries and Food, 1975). In the event, it was necessary to reduce silage intake to 1.0 times maintenance energy requirements in order to avoid silage refusals when $\mathrm{G}$ alone or $\mathrm{C}$ and $\mathrm{G}$ together were infused (see p. 91). Water and mineralized salt licks were freely available throughout the experiment and $2 \times 10 \mathrm{~g}$ chromic oxide impregnated paper/d was administered to each animal after each feed. 
Each experimental period was $21 \mathrm{~d}$ long and consisted of a $14 \mathrm{~d}$ infusion period followed by a $7 \mathrm{~d}$ rest period. The five different intraruminal infusions consisted of $\mathrm{W}, \mathrm{C}$ (Technical grade, Sigma Chemical Co Ltd, Poole, Dorset; $70 \mathrm{~g} \mathrm{C} / \mathrm{kg}$ infusate), U (General Purpose Reagent, BDH Ltd, Poole, Dorset; $35 \mathrm{~g} \mathrm{U} / \mathrm{kg}$ infusate), G (42DE; CPC Ltd, Trafford Park, Manchester; $530 \mathrm{~g} \mathrm{G} / \mathrm{kg}$ infusate) and $\mathrm{C}$ and $\mathrm{G}(35 \mathrm{~g} \mathrm{C}$ and $265 \mathrm{~g} \mathrm{G} / \mathrm{kg}$ infusate; $\mathrm{CG})$. $\mathrm{G}$ contained $(\mathrm{g} / \mathrm{kg}$ total carbohydrate) glucose, 170 ; maltose, 130; maltotriosemaltoheptose, 420; and oligosaccharides of chain-length greater than 7,280. The intention was to maintain infusion rates of $0 \cdot 11 / \mathrm{h}$ for infusates $\mathrm{W}, \mathrm{C}, \mathrm{U}$ and $\mathrm{G}$ and $0 \cdot 21 / \mathrm{h}$ for infusate $\mathrm{CG}$; in practice there were some deviations from these rates but the exact amounts of each infusate infused were recorded daily. In addition to the nutrients included in the infusates, $2.5 \mathrm{mCi} \mathrm{Na}_{2}{ }^{35} \mathrm{SO}_{4}$ were added to each infusate at 09.00 hours on day 12 of each infusion period and this infusion of ${ }^{35} \mathrm{~S}$ was maintained until the completion of the $24 \mathrm{~h}$ collection of duodenal digesta. On the final day of each infusion period (day 14), beginning at 08.00 hours, a $24 \mathrm{~h}$ complete collection of duodenal digesta was made from each animal. In addition, sixteen samples of rumen fluid were obtained at 1-5-h intervals from 09.00 hours on day 14. Details of the sampling procedure and of the preparation of a duodenal microbial fraction have been given by Rooke et al. (1985 b).

\section{Analytical procedures}

The procedures used in the analysis of the silage, infusates, rumen fluid, duodenal digesta and the duodenal microbial samples have been described (Rooke et al. 1985 b). Additionally, the ethanol content of the silage was determined according to Böttcher (1982) and the free glucose plus $\alpha$-linked glucose polymer contents of the infusates and duodenal digesta samples were determined according to MacRae \& Armstrong (1969).

\section{Calculation of results}

Flows of digesta dry matter (DM) entering the small intestine were corrected for complete recovery of $\mathrm{Cr}_{2} \mathrm{O}_{3}$ administered daily. The intake of soluble $\mathrm{CHO}$ was calculated as the sum of silage water-soluble $\mathrm{CHO}$ (determined by the anthrone method) and infused $\mathrm{CHO}$ (determined as free glucose plus $\alpha$-linked glucose polymers); the soluble CHO content of duodenal digesta was determined as the free glucose plus $\alpha$-linked glucose polymers.

\section{Statistical analysis}

Analysis of variance was carried out on the results according to an incomplete Latin square design using a least-squares procedure. Two sets of experimental values were missing from the results due to the removal of two different animals from two different experimental periods for reasons not connected with the diets being fed, i.e. leakage of digesta from the duodenal cannula in one case and accidental temporary disconnection of the duodenal cannula and loss of digesta in the other case. Differences between each infusion and the control (water) infusion were determined using Dunnett's test (Dunnett, 1955).

\section{RESULTS}

Infusing different nutrients had no significant effects on mean rumen $\mathrm{pH}$, concentrations of volatile fatty acids or molar proportions of individual fatty acids (Table 2). Infusing either $\mathrm{C}$ or $\mathrm{U}$ significantly $(P<0.05)$ increased rumen $\mathrm{NH}_{3}-\mathrm{N}$ concentrations when compared with the infusion of $\mathrm{W}$ alone. In addition, although the differences were not significant, infusion of $\mathrm{CG}$ together or of $\mathrm{G}$ alone reduced $\mathrm{NH}_{3}-\mathrm{N}$ concentrations in comparison with the $\mathrm{W}$ infusion, with the lowest mean values for $\mathrm{NH}_{3}-\mathrm{N}$ being observed when $\mathrm{G}$ alone was infused.

The changes in rumen $\mathrm{NH}_{3}-\mathrm{N}$ concentrations throughout the day are shown in Fig. 1. 
Table 2. Mean values for $p H$ and for the concentrations of ammonia-nitrogen $(m g / l)$ and volatile fatty acids (mmol/l) in the rumen fluid of cattle given diets of grass silage and five different intraruminal infusions $\dagger$

(The molar proportions of individual fatty acids ( $\mathrm{mmol}$ acid/mol total volatile fatty acids) are also given)

\begin{tabular}{|c|c|c|c|c|c|c|c|c|}
\hline & \multicolumn{5}{|c|}{ Infusions } & \multirow[b]{2}{*}{ SE $\ddagger$} & \multicolumn{2}{|c|}{$\begin{array}{l}\text { Statistical } \\
\text { significance } \\
\text { of infusions }\end{array}$} \\
\hline & $\mathbf{W}$ & $\mathrm{C}$ & $\mathrm{U}$ & G & $\mathrm{CG}$ & & $\mathrm{U}$ & $\mathrm{C}$ \\
\hline $\mathrm{pH}$ & $6 \cdot 8$ & $6 \cdot 8$ & $6 \cdot 8$ & $6 \cdot 8$ & $6 \cdot 7$ & $0 \cdot 02$ & NS & NS \\
\hline $\mathrm{NH}_{3}-\mathrm{N}$ & 51 & 98 & 82 & 28 & 39 & $11 \cdot 1$ & $*$ & $*$ \\
\hline \multicolumn{9}{|c|}{ Volatile fatty acids } \\
\hline Total & $67 \cdot 3$ & $67 \cdot 3$ & $65 \cdot 3$ & $71 \cdot 4$ & $66 \cdot 0$ & $2 \cdot 96$ & NS & NS \\
\hline Acetic & 682 & 678 & 661 & 687 & 666 & $7 \cdot 6$ & NS & NS \\
\hline Propionic & 177 & 177 & 178 & 179 & 187 & $7 \cdot 5$ & NS & NS \\
\hline iso-Butyric & 13 & 13 & 16 & 10 & 9 & $1 \cdot 0$ & NS & NS \\
\hline n-Butyric & 82 & 83 & 83 & 86 & 96 & $3 \cdot 9$ & NS & NS \\
\hline iso-Valeric & 30 & 31 & 41 & 22 & 22 & $4 \cdot 2$ & NS & NS \\
\hline$n$-Valeric & 17 & 18 & 21 & 16 & 19 & 0.7 & NS & NS \\
\hline
\end{tabular}

W, water; C, casein; U, urea; G, glucose syrup; $C G$, casein plus glucose syrup; NS, not significant.

* $P<0.05$.

$\uparrow$ For details, see p. 91.

$\$$ SE of mean with 6 df for four observations, $G$ and $C G$ three observations only.

$\S$ No significant effects were observed for infusions $G$ and $C G$.

The significant increase observed in $\mathrm{NH}_{3}-\mathrm{N}$ concentrątions (Table 2) when $\mathrm{C}$ or $\mathrm{U}$ were infused was apparent at all sampling times as were the reductions in $\mathrm{NH}_{3}-\mathrm{N}$ concentrations observed when $\mathrm{G}$ alone or $\mathrm{G}$ plus $\mathrm{C}$ were infused. Indeed, when $\mathrm{G}$ alone was infused mean $\mathrm{NH}_{3}-\mathrm{N}$ concentrations observed between 22.30 and 06.00 hours were less than $5 \mathrm{mg}$ $\mathrm{NH}_{3}-\mathrm{N} / 1$.

The daily intakes of OM, soluble CHO and acid-detergent fibre (ADF) by the cattle, and the quantities of OM, soluble $\mathrm{CHO}$ and $\mathrm{ADF}$ entering the small intestine are shown in Table 3. Infusion of $\mathrm{C}$ or $\mathrm{U}$ had no significant effects on the quantities of $\mathrm{OM}$, soluble $\mathrm{CHO}$ or of ADF entering the small intestine daily.

However, infusion of $\mathrm{G}$ or of $\mathrm{G}$ and $\mathrm{C}$ resulted in increases in the quantities of $\mathrm{OM}(\mathrm{G}$, $P<0.05$; CG, $P<0.01$ ), soluble CHO (G, $P<0.01$; CG, $P<0.01$ ) and of ADF (G, not significant; $C G, P<0.05)$ entering the small intestine. The increase in the amounts of soluble $\mathrm{CHO}$ entering the small intestine daily were quantitatively small; indeed, when expressed as a proportion of the total soluble $\mathrm{CHO}$ intake, proportionately less soluble $\mathrm{CHO}$ entered the small intestine daily when $\mathrm{G}$ was infused alone or together with $\mathrm{C}$. However, expressed as a proportion of total $\mathrm{OM}$ and $\mathrm{ADF}$ intake, the increases in $\mathrm{OM}$ $(\mathrm{CG}, P<0.05)$ and ADF (G, $P<0.05 ; \mathrm{CG}, P<0.01)$ entering the small intestine when $G$ or $G$ and $C$ were infused were significant; the increase in $O M$ when $G$ alone was infused was not significant. Thus, inclusion of $C$ in the $G$ infusion, gave rise to greater increases in the quantities of $\mathrm{OM}$ and $\mathrm{ADF}$ entering the small intestine than were observed with $\mathrm{G}$ alone.

The quantities of total $\mathrm{N}$ (TN) and of amino acid-N (AAN) ingested as silage TN and AAN and infused intraruminally are shown in Table 4, as are the quantities of non- $\mathrm{NH}_{3}-\mathrm{N}$ (NAN) and AAN entering the small intestine. Increasing TN intake by infusing $U$ or $\mathrm{C}$, 


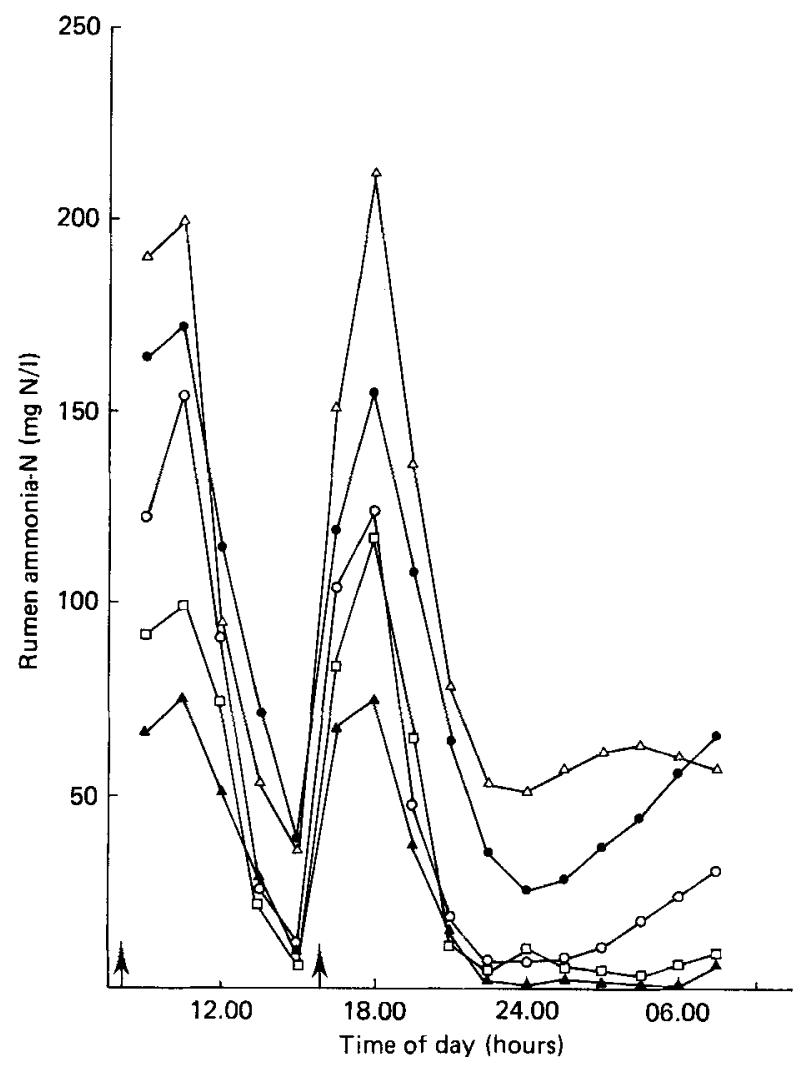

Fig. 1. Daily variations in rumen ammonia-nitrogen concentrations of cattle given grass-silage diets in two meals per $d$ ( $\uparrow$ times of feeding) supplemented with intraruminal infusions of water $(O)$, casein $(\Theta)$, urea $(\triangle)$, glucose syrup $(\boldsymbol{\Delta})$ or casein and glucose syrup $(\square)$. For details, see p. 91. Mean values for four observations are given for water, casein and urea infusions and for three observations for glucose syrup and casein and glucose syrup infusions.

and AAN intake by infusing $\mathrm{C}$, did not significantly change the quantities of NAN or AAN entering the small intestine as compared with the infusion of $\mathrm{W}$. Thus, when expressed as a proportion of TN intake, significantly smaller amounts of NAN entered the small intestine (g/g N intake) when $U(P<0.05)$ was infused. Infusion of $\mathrm{G}$ increased the quantities of NAN and AAN entering the small intestine when expressed either as g/d (NAN and AAN, $P<0.05$ ) or $\mathrm{g} / \mathrm{g} \mathrm{N}$ (or AAN) intake (NAN, $P<0.01$; AAN, $P<0.05$ ). Addition of C to the $\mathrm{G}$ infusion resulted in increases in the quantities of NAN and AAN entering the small intestine when compared with the $\mathrm{W}$ infusion (g NAN or AAN/d, $P<0.01 ; \mathrm{g} / \mathrm{g} \mathrm{N}$ (or AAN) intake, NAN, $P<0.01$; AAN, $P<0.05$ ) which were markedly greater in magnitude than those observed when $G$ alone was infused.

Table 5 shows the quantities of microbial $\mathbf{N}$ and undegraded feed (plus endogenous) $\mathrm{N}$ entering the small intestine. Infusing $\mathrm{U}$ or $\mathrm{C}$ did not significantly change the quantities of microbial $\mathbf{N}$ or of feed $\mathrm{N}$ which entered the small intestine as compared with the quantities entering the small intestine when $\mathrm{W}$ was infused. There were no significant changes in the apparent efficiency of microbial $\mathrm{N}$ synthesis when $\mathrm{U}$ or $\mathrm{C}$ were infused. The apparent degradability of feed $\mathrm{N}$ was significantly increased when $\mathrm{C}(P<0.05)$ but not $\mathrm{U}$ was infused. 
Table 3. The mean quantities $(\mathrm{kg} / 24 \mathrm{~h})$ of organic matter $(\mathrm{OM})$, soluble carbohydrate $(\mathrm{CHO})$ and acid-detergent fibre (ADF) consumed by the cattle, infused intraruminally and entering the small intestine

(The quantities of OM, soluble CHO and ADF entering the small intestine daily are also expressed as a proportion $(\mathrm{g} / \mathrm{g})$ of $\mathrm{OM}$, soluble $\mathrm{CHO}$ or $\mathrm{ADF}$ intake)

\begin{tabular}{l}
\hline \\
\end{tabular}

W, water; C, casein; U, urea; G, glucose syrup; CG, casein plus glucose syrup; NS, not significant.

$* P<0.05, * * P<0.01$.

$\dagger$ For details, see p. 91 .

$\ddagger$ SE of mean with $6 \mathrm{df}$ for four observations, $\mathrm{G}$ and CG three observations only.

$\S$ No significant effects were observed for $U$ and $C$ infusions.

Infusion of $\mathrm{G}$ significantly $(P<0.05)$ increased the microbial $\mathrm{N}$ entering the small intestine, compared with when $\mathrm{W}$ was infused. However, the increase in the efficiency of microbial $\mathrm{N}$ synthesis when $\mathrm{G}$ was infused was not significant. Addition of $\mathrm{C}$ to $\mathrm{G}$ resulted in increases in microbial $\mathrm{N}$ entering the small intestine $(P<0.01)$ and in the efficiency of microbial $\mathrm{N}$ synthesis $(P<0.05)$ compared with $\mathrm{W}$, which again were markedly greater than the increases observed when $G$ alone was infused. The infusion of $G$ alone or in conjunction with $\mathrm{C}$ did not significantly alter the quantities of feed (plus endogenous) $\mathrm{N}$ entering the small intestine or the apparent degradability of feed $\mathrm{N}$.

\section{DISCUSSION}

Digestion of silage

When silage was given alone the efficiency of microbial $N$ synthesis in the rumen observed in this experiment $22 \mathrm{~g} \mathrm{~N} / \mathrm{kg}$ OMADR was within the range of values previously observed with cattle (20-30 g N/kg OMADR; Brett et al. 1979; Thomson et al. 1981; Rooke et al. $1982,1983 a, b, 1985 a)$. The extensive fermentation of OM within the rumen and the marked diurnal fluctuations in rumen $\mathrm{NH}_{3}-\mathrm{N}$ concentrations as a result of twice-daily feeding were 
Table 4. The mean quantities of total $(T N)$ and amino acid-nitrogen $(A A N)$ consumed $(\mathrm{g} / 24 \mathrm{~h})$ by the cattle, infused intraruminally and the quantities $(\mathrm{g} / 24 \mathrm{~h})$ of non-ammonia- $N$ $(N A N)$ and $A A N$ entering the small intestine

(The quantities of NAN and AAN entering the small intestine daily are also expressed as a proportion of the quantity of TN or AAN ingested)

\begin{tabular}{|c|c|c|c|c|c|c|c|c|c|}
\hline & \multicolumn{5}{|c|}{ Infusion $†$} & \multirow[b]{2}{*}{$\mathrm{SE} \ddagger$} & \multicolumn{3}{|c|}{$\begin{array}{c}\text { Statistical } \\
\text { significance } \\
\text { of infusions } \S\end{array}$} \\
\hline & $\mathbf{w}$ & $\mathrm{C}$ & $\mathrm{U}$ & $\mathrm{G}$ & CG & & $\mathrm{U}$ & G & CG \\
\hline \multicolumn{10}{|l|}{ TN intake from } \\
\hline Silage & 94 & 95 & 90 & 86 & 86 & - & - & - & - \\
\hline Infusion & - & 21 & 28 & - & 17 & - & - & - & - \\
\hline Total & 94 & 116 & 119 & 86 & 103 & - & - & - & - \\
\hline \multicolumn{10}{|l|}{ AAN intake from } \\
\hline Silage & 64 & 62 & 61 & 57 & 57 & - & - & - & - \\
\hline Infusion & - & 18 & - & - & 14 & - & - & - & - \\
\hline Total & 64 & 80 & 61 & 57 & 71 & - & - & - & - \\
\hline \multicolumn{10}{|c|}{ NAN entering small intestine } \\
\hline $\mathrm{g} / 24 \mathrm{~h}$ & 89 & 94 & 91 & 106 & 139 & $4 \cdot 1$ & NS & * & ** \\
\hline $\mathrm{g} / \mathrm{g}$ TN intake & 0.94 & 0.81 & $0 \cdot 76$ & $1 \cdot 24$ & $1 \cdot 35$ & 0.050 & $*$ & ** & ** \\
\hline \multicolumn{10}{|c|}{ AAN entering small intestine } \\
\hline $\mathrm{g} / 24 \mathrm{~h}$ & 61 & 68 & & 75 & 94 & $2 \cdot 7$ & NS & * & ** \\
\hline g/g AAN intake & $0-97$ & 0.85 & 1.04 & $1 \cdot 32$ & 1.33 & 0.064 & NS & * & $*$ \\
\hline
\end{tabular}

W, water; C, casein; U, urea; G, glucose syrup; CG, casein plus glucose syrup; NS, not significant.

$* P<0.05,{ }^{* *} P<0.01$.

+ For details, see p. 91 .

$\ddagger$ SE of mean with $6 \mathrm{df}$ for four observations, $\mathrm{G}$ and $\mathrm{CG}$ three observations only.

$\S$ No significant effects were observed for $\mathrm{C}$ infusion.

also in line with previous observations. The low efficiencies of rumen microbial $\mathrm{N}$ synthesis when ruminants were fed on silage have been variously related (1) to low yields of $A T P / \mathrm{kg}$ OMADR because of the presence of fermentation end-products in the silage OM (Thomas, 1982), (2) to poor synchronization of the rates of $N$ and energy release from silage leading to a low efficiency of $\mathrm{N}$ capture by the rumen micro-organisms and consequent losses of $\mathrm{NH}_{3}$ across the rumen wall (Siddons et al. 1985) or (3) to the form in which rumendegradable $\mathrm{N}$ is present in silage, i.e. as amino acids and $\mathrm{NH}_{3}$ (Rooke et al. 1985a).

\section{Infusion of casein or urea}

Previous experiments (Brett et al. 1979; Rooke et al. 1983a, 1985a) showed that the stimulation in the efficiency of rumen microbial $\mathrm{N}$ synthesis observed when silage was supplemented with soya-bean meal was associated with increases in rumen $\mathrm{NH}_{3}-\mathrm{N}$ concentrations such that the values of less than $50 \mathrm{mg} \mathrm{N} / 1$ observed between feeds when soya-bean meal was not present were elevated above $50 \mathrm{mg} \mathrm{N} / 1$ when the meal was included in the diet. In the present experiment, $\mathrm{U}$ or $\mathrm{C}$ were continuously infused intraruminally in an attempt to clarify the basis of the stimulation of rumen microbial $\mathrm{N}$ synthesis obtained with soya-bean-meal supplementation. $U$ was infused to determine whether the stimulation resulted from an improved synchronization of the rates of release in the rumen of $\mathrm{NH}_{3}$ and energy, whereas $\mathrm{C}$ was infused to determine whether the supply of amino acids and peptides from degraded protein- $\mathrm{N}$ was important. As expected $\mathrm{U}$ and $\mathrm{C}$ improved $\mathrm{N}$ supply to the 
Table 5. Mean quantities $(g / 24 h)$ of microbial total nitrogen $(T N)$ entering the small intestine and the apparent efficiency of microbial $N$ synthesis in the rumen $(g N / k g$ organic matter apparently digested in the rumen)

(Also shown are values for the apparent quantities $(\mathrm{g} / 24 \mathrm{~h}$ ) of feed non-ammonia-N (NAN) entering the small intestine, together with values for the apparent degradability of feed $\mathrm{TN}$ within the rumen)

\begin{tabular}{|c|c|c|c|c|c|c|c|c|c|}
\hline & \multicolumn{5}{|c|}{ Infusiont } & \multirow[b]{2}{*}{ SE $\ddagger$} & \multicolumn{3}{|c|}{$\begin{array}{c}\text { Statistical } \\
\text { significance } \\
\text { of infusions } \S\end{array}$} \\
\hline & W & $\mathrm{C}$ & $\mathbf{U}$ & $\mathrm{G}$ & $\mathrm{CG}$ & & $\mathrm{C}$ & $\mathrm{G}$ & $\mathrm{CG}$ \\
\hline $\begin{array}{l}\text { Microbial TN entering small } \\
\text { intestine }\end{array}$ & 63 & 75 & 68 & 81 & 109 & $4 \cdot 5$ & NS & * & $* *$ \\
\hline $\begin{array}{l}\text { Efficiency of microbial TN } \\
\text { synthesis }\end{array}$ & 22 & 25 & 25 & 27 & 38 & $2 \cdot 7$ & NS & NS & * \\
\hline $\begin{array}{l}\text { Feed } \mathrm{N} \text { entering small } \\
\text { intestine } \|\end{array}$ & 22 & 19 & 24 & 23 & 28 & $2 \cdot 4$ & NS & NS & NS \\
\hline $\begin{array}{l}\text { Apparent feed TN } \\
\text { degradability }\end{array}$ & 0.76 & 0.83 & 0.80 & 0.73 & 0.72 & 0.019 & $*$ & NS & NS \\
\hline
\end{tabular}

W, water; C, casein; U, urea; G, glucose syrup; CG, casein plus glucose syrup; NS, not significant.

* $P<0.05,{ }^{* *} P<0.01$.

$\dagger$ For details, see p. 91 .

$\ddagger$ SE of mean with $6 \mathrm{df}$ for four observations, $\mathrm{G}$ and $\mathrm{CG}$ three observations only.

$\S$ No significant effects of $\mathrm{U}$ infusion.

$\|$ Includes endogenous $\mathbf{N}$ secretions. Values for degradability of feed $\mathbf{N}$ calculated from the difference between

TN intake and duodenal (NAN-microbial TN).

rumen micro-organisms as both infusions elevated rumen $\mathrm{NH}_{3}-\mathrm{N}$ concentrations over the $24 \mathrm{~h}$ sampling period (see Fig. 1). However, only small and non-significant increases in the quantity of microbial $\mathrm{N}$ synthesized and in the efficiency of microbial $\mathrm{N}$ synthesis in the rumen were observed. These results indicate that it was not a shortage of rumen $\mathrm{NH}_{3}-\mathrm{N}$ per se that was limiting the efficiency of rumen microbial synthesis when silage was fed. Furthermore, the failure of $\mathrm{C}$ to stimulate microbial $\mathrm{N}$ synthesis suggested that a supply of additional AAN or peptide- $N$ was not an important limiting factor. The present experiment did not, therefore, provide any explanation for the stimulation of microbial $\mathrm{N}$ synthesis by soya-bean meal observed previously.

\section{Infusion of $G$}

Infusion of $\mathrm{G}$ alone reduced rumen $\mathrm{NH}_{3}-\mathrm{N}$ concentrations throughout the $24 \mathrm{~h}$ sampling period to such an extent that between 24.00 and 06.00 hours rumen $\mathrm{NH}_{3}-\mathrm{N}_{\text {concentrations }}$ were frequently below the limits of detection of the assay procedure used $(<2 \mathrm{mg} \mathrm{N} / 1)$. Thus, $\mathrm{G}$ reduced $\mathrm{NH}_{3}-\mathrm{N}$ concentrations markedly in agreement with Syrjala (1972) and the recent observations of Chamberlain et al. (1985). Rumen $\mathrm{NH}_{3}-\mathrm{N}$ concentrations were also lower than those in experiments where silage was supplemented with barley (Rooke et al. 1985a), again in agreement with the results of Syrjala (1972) and Chamberlain et al. (1985) where direct comparisons between starch and sucrose in reducing $\mathrm{NH}_{3}-\mathrm{N}$ concentrations were made. The observed reduction in rumen $\mathrm{NH}_{3}-\mathrm{N}$ concentration was accompanied by a 1.2-fold increase in the quantities of NAN which entered the small intestine daily, in agreement with the results of Gill \& Ulyatt (1977). As suggested by Gill \& Ulyatt (1977), the increase in the quantities of NAN which entered the small intestine was mediated entirely by an increase in the quantities of microbial $\mathbf{N}$ synthesized within the rumen. 
Chamberlain et al. (1985) have also suggested that the reduction in $\mathrm{NH}_{3}-\mathrm{N}$ concentrations mediated by sucrose supplementation reflected increased microbial $\mathrm{N}$ synthesis within the rumen. The results from the present experiment, therefore, have confirmed experimentally the suggestions made by Gill \& Ulyatt (1977) and by Chamberlain et al. (1985).

The increase in the quantities of microbial $N$ entering the small intestine when $G$ was infused was accompanied by only a small increase in the efficiency of rumen microbial $\mathrm{N}$ synthesis (22-27 g N/kg OMADR). Since the mean rumen $\mathrm{NH}_{3}-\mathrm{N}$ concentration when $\mathrm{G}$ was infused was only $28 \mathrm{mg} \mathrm{N} / 1$ it is probable that $\mathrm{NH}_{3}$ supply was limiting microbial $\mathrm{N}$ synthesis (see Miller, 1982). Addition of $\mathrm{C}$ to the $\mathrm{G}$ infusate resulted in the mean rumen $\mathrm{NH}_{3}-\mathrm{N}$ concentration increasing from 28 to $39 \mathrm{mg} \mathrm{N} / \mathrm{l}$ with corresponding increases in both the quantities of microbial $\mathrm{N}$ synthesized and the efficiency of synthesis. Thus the supply of $\mathrm{N}$ or amino acids to the micro-organisms was apparently limiting microbial $\mathrm{N}$ synthesis when $G$ alone was infused; whether infusion of $U$ would have been as effective as $C$ is currently under investigation.

Thomson et al. (1981) calculated values for the ratio of rumen-degradable CHO (DC): degradable $\mathrm{N}$ (DN) in calves fed on grass silages and found that an increase in the ratio from 18 to 32 was associated with an increase in the apparent efficiency of capture of degraded $\mathrm{N}$ in the rumen from 65 to $95 \%$ and an increase in efficiency of microbial $\mathrm{N}$ synthesis from 24 to $29 \mathrm{~g} \mathrm{~N} / \mathrm{kg}$ OMADR. In agreement with Thomson et al. (1981) infusion of $\mathrm{G}$ increased DC:DN from 49 when $\mathrm{W}$ was infused to 57 , the apparent efficiency of capture of degraded $\mathrm{N}$ in the rumen from 88 to $129 \%$ and the efficiency of microbial $\mathrm{N}$ synthesis from 22 to $27 \mathrm{~g} \mathrm{~N} / \mathrm{kg}$ OMADR. In contrast, however, addition of $\mathrm{C}$ to $\mathrm{G}$ reduced DC:DN from $57(\mathrm{G})$ to 46 (CG) yet the apparent efficiency of capture of degraded $\mathrm{N}$ increased from 129 to $145 \%$ and the efficiency of microbial $\mathrm{N}$ synthesis from 27 to $38 \mathrm{~g}$ $\mathrm{N} / \mathrm{kg}$ OMADR. This contrasting observation probably reflects the improved synchronization of supply of energy and of $\mathrm{N}$ for microbial synthesis and in part the well-documented synergistic effect of supplying a mixture of structural and non-structural $\mathrm{CHO}$ in the diet on the efficiency of rumen microbial $\mathrm{N}$ synthesis (e.g. Offer et al. 1978; Mathers \& Miller, 1981).

Calculation of DC:DN also demonstrates the improved capture of degraded $\mathrm{N}$ within the rumen resulting from the infusion of $G$ alone or in conjunction with $C$, such that a net loss of $\mathrm{N}$ between the mouth and small intestine of $1.0 \mathrm{~g} \mathrm{~N} / \mathrm{kg} \mathrm{OM}$ intake when silage was given alone was translated into net gains of 3.9 and $6.8 \mathrm{~g} \mathrm{~N} / \mathrm{kg} \mathrm{OM}$ intake when $\mathrm{G}$ or $\mathrm{G}$ and $\mathrm{C}$ were infused intraruminally. The change from net loss to a net gain of $\mathrm{N}$ across the forestomachs as a result of $\mathrm{CHO}$ infusion is in agreement with the concepts (Kennedy \& Milligan, 1980) that (1) the transfer of endogenous urea to the rumen is inversely related to the rumen $\mathrm{NH}_{3}-\mathrm{N}$ concentration, and (2) that the addition of sucrose to the diet markedly increases the clearance of plasma $U$ to the rumen. The additional net gain of $\mathrm{N}$ across the forestomachs observed when $C$ and $G$ were infused might be caused by increased plasma $\mathrm{U}$ concentrations as a result of catabolism of additional quantities of amino acids absorbed from the small intestine.

The results from the present experiment have shown that in agreement with other workers (Syrjala, 1972; Gill \& Ulyatt, 1977; Chamberlain et al. 1985) the utilization of silage $N$ for rumen microbial $\mathrm{N}$ synthesis is markedly improved by the provision of soluble $\mathrm{CHO}$ for rumen fermentation. However, the practical advantages in improving animal performance through the use of soluble CHO may be limited to some extent by the reduction in the extent of fibre digestion which occurred within the rumen when soluble $\mathrm{CHO}$ was infused in the present experiment and the likely reductions in voluntary food intake of the silage caused by this inhibition of fibre digestion. In the present experiment, silage intake had to be reduced to avoid refusals when $G$ was infused. Similarly, when England \& Gill (1985) gave 
increasing amounts of sucrose to calves as a supplement to ad lib. silage, a progressive reduction in both the apparent digestibility of silage cellulose and in silage intake was observed.

The authors are grateful to the Agricultural and Food Research Council and to the Korea Science and Engineering Foundation for financial support; to Messrs Brian Brown, George Graham and David Smith for the care and maintenance of the cattle; to Miss Ann Purvis for technical assistance and to Rowntree Mackintosh plc, Fawdon, Newcastle for providing the glucose syrup.

\section{REFERENCES}

Agricultural Research Council (1984). The Nutrient Requirements of Ruminant Livestock Supplement, no. 1. Slough: Commonwealth Agricultural Bureaux.

Böttcher, W. (1982). Archiv für Tierernährung 32, 287-394.

Brett, P. A., Almond, M., Harrison, D. G., Rowlinson, P., Rooke, J. A. \& Armstrong, D. G. (1979). Proceedings of the Nutrition Society 38, 148A.

Chamberlain, D. G., Thomas, P. C. \& Wait, M. K. (1982). Grass and Forage Science 37, 159-164.

Chamberlain, D. G., Thomas, P. C., Wilson, W., Newbold, C. J. \& McDonald, J. C. (1985). Journal of Agricultural Science, Cambridge 104, 331-340.

Dunnett, C. W. (1955). Journal of the American Statistical Association 50, 1096-1121.

England, P. \& Gill, M. (1985). Animal Production 49, 259-265.

Gill, M. \& Ulyatt, M. J. (1977). Journal of Agricultural Science, Cambridge 89, 43-51.

Kennedy, P. M. \& Milligan, L. P. (1980). Canadian Journal of Animal Science 60, 205-221.

McDonald, P. (1981). The Biochemistry of Silage. Chichester: John Wiley \& Sons Ltd.

McMeniman, N. P. \& Armstrong, D. G. (1979). Journal of Agricultural Science, Cambridge 93, 181-188.

MacRae, J. C. \& Armstrong, D. G. (1969). British Journal of Nutrition 23, 15-23.

Mathers, J. C. \& Miller, E. L. (1981). British Journal of Nutrition 45, 587-604.

Miller, E. L. (1982). In Forage Protein in Ruminant Animal Production, Occasional Publication of the British Society of Animal Production no. 6, pp. 79-88 [D. J. Thomson, D. E. Beever and R. G. Gunn, editors]. Thames Ditton: British Society of Animal Production.

Ministry of Agriculture, Fisheries and Food (1975). Energy Allowances and Feeding Systems for Ruminants. Technical Bulletin no. 33. London: H.M. Stationery Office.

Offer, N. W., Axford, R. F. E. \& Evans, R. (1978). British Journal of Nutrition 40, 35-44.

Rooke, J. A., Brett, P. A., Overend, M. A. \& Armstrong, D. G. (1985a). Animal Feed Science and Technology 13, 255-267.

Rooke, J. A., Brookes, I. M. \& Armstrong, D. G. (1982). In Forage Protein in Ruminant Animal Production, Occasional Publication of the British Society of Animal Production no. 6, pp. 185-186 [D. J. Thomson, D. E. Beever and R. G. Gunn, editors]. Thames Ditton: British Society of Animal Production.

Rooke, J. A., Brookes, I. M. \& Armstrong, D. G. (1983a). Journal of Agricultural Science, Cambridge 100, 329-342.

Rooke, J. A., Greife, H. A. \& Armstrong, D. G. (1983b). Grass and Forage Science 38, 302-310.

Rooke, J. A., Greife, H. A. \& Armstrong, D. G. (1985b). British Journal of Nutrition 53, 691-708.

Siddons, R. C., Evans, R. T. \& Beever, D. E. (1979). British Journal of Nutrition 42, 535-545.

Siddons, R. C., Nolan, J. V., Beever, D. E. \& MacRae, J. C. (1985). British Journal of Nutrition 54, $175-187$.

Syrjala, L. (1972). Annales Agriculturae Fenniae 11, 199-276.

Thomas, P. C. (1982). In Forage Protein in Ruminant Animal Production, Occasional Publication of the British Society of Animal Production no. 6, pp. 67-78 [D. J. Thomson, D. E. Beever and R. G. Gunn, editors]. Thames Ditton: British Society of Animal Production.

Thomas, P. C., Chamberlain, D. G., Kelly, N. C. \& Wait, M. K. (1980). British Journal of Nutrition 43, 469-480.

Thomson, D. J., Beever, D. E., Lonsdale, C. R., Haines, M. J., Cammell, S. B. \& Austin, A. R. (1981). British Journal of Nutrition 46, 193-208. 